\title{
Response of bay scallops to spawner transplants: a test of recruitment limitation
}

\author{
Charles H. Peterson*, Henry C. Summerson, Richard A. Luettich, Jr \\ University of North Carolina at Chapel Hill, Institute of Marine Sciences, Morehead City, North Carolina 28557, USA
}

\begin{abstract}
Adult bay scallops Argopecten irradians concentricus Say were transplanted prior to spawning in summer 1992 (135000), 1993 (100000), and 1994 (150000) from a donor site where scallops were abundant to receiver sites in western Bogue Sound, North Carolina, USA, an estuarine water basin where scallops had not initiated recovery since their virtual elimination by a red tide outbreak in 1987-1988. Transplantation enhanced local adult density in receiver sites from <1 in 1992 and 1993 and 3 in 1994 to $15 \mathrm{~m}^{-2}$ These transplants were intended as a test of the hypothesis that bay scallop populations are recruitment-limited on a basin scale within sounds, which is consistent with the limited physical transport of their short-lived pelagic larvae. This intervention also represents an empirical test of a process-based restoration option (spawner transplantation) with broad significance to managers of shellfish resources. Both mortality and emigration were negligible from August to December for transplanted scallops at each of the 4 receiver sites in western Bogue Sound. On average, recruitment of scallops at 2 study sites in western Bogue Sound following the transplants in 1992, 1993, and 1994 was $568 \%$ greater than in 1988 and 1989 when no transplantation had occurred. At 2 control sites in Back and Core Sounds, North Carolina, USA, the average change in recruitment was a non-significant $34 \%$ increase over this same period. Adult density in Bogue Sound increased by $258 \%$ following spawner transplantation as compared to a non-significant change of $8 \%$ in control sounds. The absolute magnitude of the temporal increase in recruitment of bay scallops to natural seagrass beds was significantly larger in western Bogue Sound than in the control sounds, demonstrating a positive effect of the transplants on bay scallop restoration. Larval settlement onto spat collectors at 3 of those same study sites did not correlate well with recruitment data and failed to reveal enhancement in western Bogue Sound following transplantation. Thus, spat collector data cannot confirm that the transplants succeeded through the mechanism of enhancing larval abundances. Nevertheless, settlement of scallop spat onto collectors deployed along a transect in the channel revealed a pattern of decreasing settlement with distance from Bogue Inlet, which is consistent with the hypothesis that scallop larvae become depleted with distance from their source and thus limit population size in this system. Furthermore, larval settlement onto collectors and recruitment to natural seagrass beds were negligible at a site in central Bogue Sound that lies outside the influence of tidal forcing from Bogue lnlet and is disconnected hydrographically from the source of competent larvae in western Bogue Sound. Thus, recruitment appears to limit population size of bay scallops in this system, implying that larval subsidy from transplantation is the likely although unconfirmed mechanism of successful enhancement of recruitment following spawner transplantation.
\end{abstract}

KEY WORDS: Restoration - Recruitment limitation - Transplantation Bay scallop

\section{INTRODUCTION}

The emerging field of restoration ecology places great demands on the basic science of ecology, demands that often quickly expose the limits of our eco-

•E-mail: cpeters@email.unc.edu logical understanding. Restoration ecology requires sufficient knowledge of the processes that organize communities and limit population sizes to generate reliable predictions of the consequences of potential interventions proposed as restoration alternatives (e.g Jordan et al. 1990). Because of the extent of our present ignorance about population and community controls in nature, a legitimate concern is commonly 
expressed that restoration actions may do more harm than good in degraded ecosystems and that allowing natural recovery to take place is the wisest policy. Unfortunately, this attitude of caution and distrust fails to exploit the wisdom that has been gained from fundamental advances in ecological science.

We propose one resolution of this dilemma as to whether no active restoration should be conducted in order to avoid further unexpected ecological damage or whether to intervene in the natural system and try to apply what is known about ecology in the natural system in order to promote recovery. We suggest that the science of ecology can be properly used to generate restoration options in the form of testable hypotheses about the consequences of potential restoration interventions and that scientific methodologies of field ecology can then be further employed to develop tests of those hypotheses. Such an approach of feasibility testing represents a melding of basic and applied ecology in that the scientific activity is motivated by societal interest in some ecosystem goods or services, which then stimulates the development and testing of hypotheses that not only address the practical restoration issue but also advance fundamental ecological understanding Such an approach is the basis of adaptive management (Walters 1986)

We previously used arguments developed from 'supply-side' ecology (Underwood \& Fairweather 1989) and the theory of recruitment limitation (Gaines \& Roughgarden 1985) in population ecology to propose an explanation for the failure of the bay scallop in North Carolina, USA, to recover from the toxic effects on its population caused by the red tide outbreak of 1987-1988 (Peterson \& Summerson 1992). This outbreak of Ptychodiscus brevis from October 1987 through February 1988 was not uniformly distributed among the scallop grounds of North Carolina (Tester et al. 1991). Instead, the Ptychodiscus brevis bloom was most intense and most prolonged in Bogue Sound and Back Sound, much less pervasive in Core Sound, and essentially absent from Pamlico Sound. The resulting pattern of adult mortality and immediate recruitment failure of bay scallops matched this geographic pattern of red tide intensity (Summerson \& Peterson 1990). From 1987 until 1991, bay scallop abundance in western Bogue Sound remained grossly depressed without signs of even the initiation of recovery, despite persistence of normal populations in Pamlico and Core Sounds and recovery in Back Sound. Peterson \& Summerson (1992) suggested that this basin-scale coherence of population dynamics of bay scallops might best be explained by assuming that bay scallop abundances in traditionally productive scallop grounds are limited by recruitment and that the bay scallop population in hydrologically iso- lated western Bogue Sound was slow to recover from the effects of the red tide because the effective spawning stock for that basin was too depleted to provide an adequate supply of larvae for population recovery. This explanation is based upon the growing scientific understanding of the importance and role of recruitment limitation among marine animals (e.g. Underwood \& Denley 1984, Gaines \& Roughgarden 1985, Butman 1987, Eckman 1987, Doherty \& Williams 1988, Sammarco \& Andrews 1989, Doherty \& Fowler 1994).

Here we provide results of one test of the hypothesis that recruitment limitation exists on a basin scale for bay scallop populations within estuarine water basins and is a substantial cause of the multi-year failure of bay scallops to recover in western Bogue Sound from. damages inflicted by the $1987-1988$ red tide outbreak. We describe how bay scallop recruitment changed after transplanting of adult scallops into western Bogue Sound prior to spawning in each of 3 successive summers. As a control for natural temporal variation in recruitment of bay scallops, we also made and present the same sets of observations at control sites in Core and Back Sounds where no adult transplantation took place. Results of this experiment represent simultaneously a test of the fundamental ecological question of whether recruitment limits abundance of bay scallops in this system and also a test of feasibility of a restoration intervention (spawner transplants; see Kassner \& Malouf 1982) designed to promote recovery of an important fishery resource previously damaged by a natural disaster.

\section{METHODS}

Testing alternative transplantation techniques. To minimize or avoid mortality of adult bay scallops Argopecten irradians concentricus Say during transplantation among sounds, we first tested how scallops survived each of several conceivable alternative transplant methods. Bay scallops are relatively vulnerable to death from environmental stresses, such as high turbidity (Duggan 1973), salinity reduction (Mercaldo \& Rhodes 1982, Tettelbach et al. 1985), and temperature extremes (Belding 1910, Gutsell 1930), so we were concerned with developing a transplant process that would avoid mortaljty induced by exposure to the typically warm air temperatures of summer in North Carolina.

We measured mortality rates of adult bay scallops collected from Oscar Shoal in Back Sound (see Irlandi 1994, Fig 1 therein) and held under 5 different sets of environmental conditions for a period of $6 \mathrm{~h}$, the approximate maximal length of time needed to com- 
plete transfer from Back Sound to western Bogue Sound. Scallops were collected by hand from Oscar. Shoal, transported for $1 \mathrm{~h}$ by boat in plastic coolers, and then held either (1) out of water under refrigeration at $10^{\circ} \mathrm{C}_{i}(2)$ in mesh bags used as controls suspended in the waters of central Bogue Sound from the dock on which flow treatments were also established; (3) in a flow-through seawater system with flow rate of $0.267 \mathrm{l}$ $\mathrm{s}^{-1}$ sufficient to retain ambient $\mathrm{O}_{2}$ concentrations; (4) in the same flow-through seawater system but with flows reduced to $0.028 \mathrm{l} \mathrm{s}^{-1}$ so that $\mathrm{O}_{2}$ concentrations were allowed to fall by 50 percent; or (5) in the same flowthrough seawater system with a flow $\left(0.067 \mathrm{l} \mathrm{s}^{-1}\right)$ and $\mathrm{O}_{2}$ concentration intermediate to the fast- and slowflow conditions. These alternative methods mimic the conditions that bay scallops would experience under transport in refrigerated trucks (1) or in transport on a barge or boat with a flow-through seawater system, where water is pumped at various alternative rates (3 to 5)

Varying flow treatments were achieved by using a battery-run bilge pump to pump seawater from beneath the dock via hoses with a series of T-connectors and valves to control flow rates. Ends of the hoses fed three $5 \mathrm{gal}$ (ca 19 l) plastic buckets, each of which held 300 adult bay scallops. Flow entered at the bottom of each bucket and overflow left over the top edge. Two separate runs of this test were conducted, on 12 and 13 July 1992, providing replication for analysis. Flow rate, water temperature, and $\mathrm{O}_{2}$ concentration were measured at hourly intervals during the course of the second run for all treatments in seawater Scallops were shaded from direct exposure to sunlight in all 5 treatments. All treatments were tested simultaneously, employing 300 replicate scallops in each treatment. At the termination of both runs of this experiment, 10 individual scallops from each treatment were opened and their gonads examined for evidence of induction of spawning. Fewer than 20 percent of scallops had advanced beyond the slightly ripe stage at this time and none showed signs of having spawned, implying that our transplant procedures did not induce spawning.

An additional test was conducted to evaluate the mortality rate for adult bay scallops kept out of water and transported inside insulated plastic coolers. Scallops were collected on 16 July 1992 from Oscar Shoal in Back Sound for this experiment: 120 scallops were placed into each of 8 coolers, representing 2 replicates for each of 4 holding time treatments $(1.75,2.5,3.25$, and $4 \mathrm{~h}$ ). Scallops inside the coolers were kept moist by use of wetted cloths and cool by inclusion of a frozen 'blue ice' container in each cooler. Care was taken that no scallop lay in contact with the ice. Two control groups of 120 scallops each were placed inside plastic mesh enclosures and retained on the seafloor at a shallow subtidal location at Oscar Shoal. The scallops in the cooler treatments were all transported by boat to a location in Bogue Sound to simulate the transport itself After the assigned holding times had elapsed. scallops in each cooler were transferred to separate plastic mesh enclosures ( 1 for each cooler) identical to the one used to hold control scallops. Mortality of the scallops was assessed by examining the condition of each scallop in every mesh enclosure after 1 and $2 \mathrm{~d}$ had passed. A hand-held thermometer was used to measure the air temperature inside the coolers upon their reopening and in the ambient seawater at those same times. On the second day, upon termination of this experiment, 8 replicate scallops from each replicate of each treatment were opened and examined for evidence of spawning. None showed visible signs of induced spawning.

Fates of scallops after transplantation. Transplantation of adult bay scallops from a single donor site at Oscar Shoal in Back Sound into sites in western Bogue Sound was conducted in mid-summer during 1992, 1993, and 1994. In each year, scallops were moved on 2 occasions, about half in late July (17 to $30)$ and the rest at the next low tide sequence 2 wk later in early to mid-August (1 to 13) The total number of bay scallops moved was 135000 in 1992, 100000 in 1993, and 150000 in 1994 . The transplantation method chosen on the basis of results of testing among the 5 alternatives was to place the scallops moist but out of water inside insulated coolers for the 2 to $4 \mathrm{~h}$ move in a motorboat from the estuarine seafloor at Oscar Shoal to the receiver sites. In 1992, 3 receiver sites (Guthrie Point, Goose Creek, and Saunders Creek, North Carolina) were located in seagrass beds in a transect along the north side of the Intracoastal Waterway, spaced at about $1.5 \mathrm{~km}$ intervals, while the fourth site (Emerald Isle, North Carolina) was located in an embayment near Bogue Banks where the highest concentration of bay scallops traditionally had occurred (Fig. 1). In 1993, all 4 receiver sites (Emerald Isle, Piney Island, Wood Island, Bean Island) were located on the south side of Bogue Sound in that same embayment between the dredge spoil islands along the Intracoastal Waterway and the Bogue Banks shore (Fig 1). In 1994, a set of 8 receiver sites was selected including all those used in 1993 plus 4 additional unnamed sites east of the others (Fig 1). Each receiver site contained an extensive seagrass meadow within which rectangular plots of $1200 \mathrm{~m}^{2}$ were marked off with metal stakes to denote the specific transplant location.

In each year, sampling was conducted within several seagrass beds in western Bogue Sound in early June to estimate densities of adult bay scallops in the relevant 


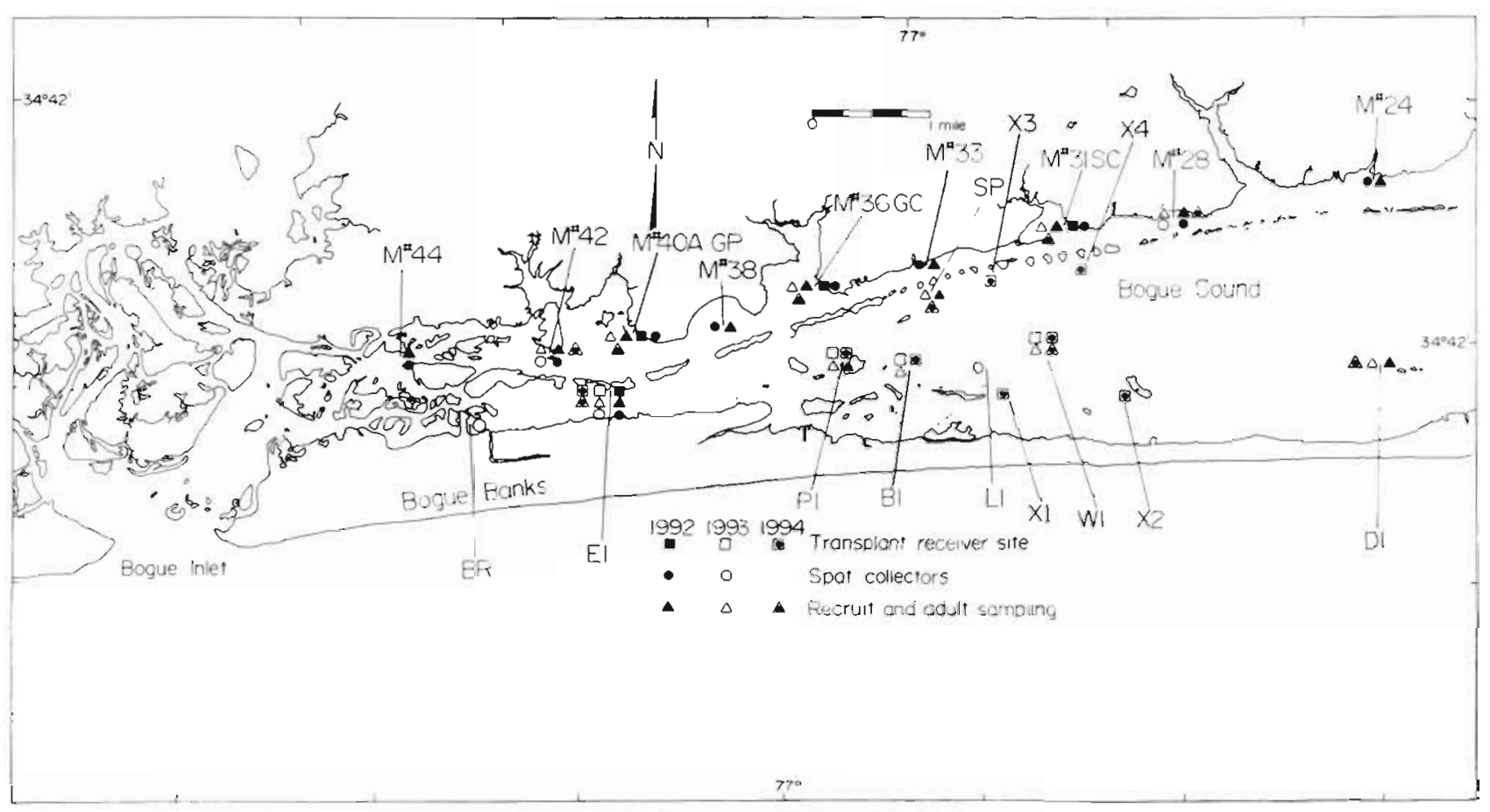

Fig. 1 Study area in North Carolina, USA, showing the 4 receiver sites for transplants in 1992 (GP: Guthrie Point; GC: Goose Creek; SC: Saunders Creek; and EI: Emerald Isle), the 4 receiver sites for 1993 transplants (C: Wood Island; BI: Bean Island; PI: Piney Island; and EI), and the 8 receiver sites for 1994 transplants (C, BI, PI, and EI plus 4 unnamed sites: X1, X2, X3, and X4), the locations of spat collectors in 1992 and 1993, the sites where scallop recruit and adult abundance was estimated by suction dredge sampling in 1992, 1993, and 1994, and the 3 sites chosen for measurement of vertical profiles in physical parameters (Markers 42 36, and 28). BR refers to the Emerald Isle bridge site and LI to the Long Island site, 2 of the locations receiving scallop spat collectors in 1993

seagrass habitat within this estuarine basin prior to transplantation. Sampling was carried out by counting numbers of adult bay scallops inside 5 to 7 haphazardly placed replicate $2 \mathrm{~m}^{2}$ quadrats at sites distributed from Dog Island to the Emerald Isle bridge (Fig. 1) In 1992, the average density of bay scallops at each of 15 seagrass beds ranged from 0 to $1.8 \mathrm{~m}^{-2}$, with a mean of 0.7 In 1993, the average density of bay scallops at each of 24 seagrass beds ranged from 0 to $3.9 \mathrm{~m}^{-2}$, with a mean of 0.9 . In 1994, the average density of bay scallops at each of 21 seagrass beds ranged from 0.1 to $18 \mathrm{~m}^{-2}$, with a mean of 2.9 .

Sampling was conducted at each receiver site to assess the fate of transplanted adult scallops. At each receiver site scallops were placed within the perimeter of the rectangular $1200 \mathrm{~m}^{2}$ area of seagrass (mostly Halodule wrightil with some Zostera marina) measuring about $30 \times 40 \mathrm{~m}$ (except at Emerald Isle, where the shape of the seagrass bed required use of a $20 x$ $60 \mathrm{~m}$ plot). Sufficient numbers of transplanted adult bay scallops were added to receiver sites to bring the densities after transplantation to approximately 15 scallops $\mathrm{m}^{-2}$. Mortality of the scallops resulting from the stress of handling during transport was estimated by placing a subset of 300 scallops inside plastic mesh holding trays at every receiver site (2 per site in 1992 and 1 in 1993) and assessing their survivorship for $48 \mathrm{~h}$ after transplantation. In 1992 intensive sampling of bay scallops in and around the immediate transplant area was conducted in early July 2 wk before and on 7 occasions after transplanting began, ending in early December. Sampling was achieved by counting the numbers of adult bay scallops inside $2 \mathrm{~m}^{2}$ quadrats haphazardly positioned at low tide inside the transplant perimeter. Additional sampling by the same method was also conducted on those same sampling dates in a perimeter strip of the seagrass bed of equal area that surrounded the transplant site on all sides. This supplemental sampling was intended to test for evidence of any emigration of the scallops, so as to permit mortality to be distinguished from emigration if numbers within the transplant site were observed to decline.

Effectiveness of the spawner transplants. To assess whether transplantation of pre-spawning adult bay scallops made any contribution to the restoration of succeeding generations of the bay scallop population in western Bogue Sound, we conducted 2 types of sam- 
pling. First, we fabricated and deployed scallop spat collector bags identical to those that we had used previously to provide a quantified index of bay scallop settlement intensity (Ambrose et al. 1992, Peterson \& Summerson 1992). These spat collectors consisted of an 'onion bag' of $5 \mathrm{~mm}$ mesh containing a $0.23 \mathrm{~m}^{2}$ piece of $4 \mathrm{~mm}$ black polyethylene mesh, which was attached by rope to a cement anchor. Each bag was held vertical in the water column by enclosed floats that maintained it at an elevation of $0.5 \mathrm{~m}$ above the bottom. Twenty replicate spat collector bags were deployed at 1 location in western Bogue Sound (Emerald Isle) and 1 location in both Core Sound (Yellow Shoal) and Back Sound (Banks Bay) (see Fig. 1). This design represents 1 treatment site in western Bogue Sound, where impact of the transplants, if any, would be expected and 2 control sites in Core and Back Sounds, where no transplantation took place.

Deployment of the spat collectors occurred only in 1992 and 1993 during the first week of September ( 3 to 8 ) with retrieval in the last week of October $(28$, 29 ) each year. This timing matches identically the timing of deployment of identically constructed spat collectors in 1988 and 1989 at those same 3 sites. At retrieval, all bags were marked to indicate source location and moved to a protected location in eastern Bogue Sound where no further scallop settlement occurred. Over the succeeding 2 mo, all bay scallops that had settled in the bags were counted, with bags drawn equally from each location on every counting day. This design therefore precisely replicates the design used in both 1988 and 1989, which represent 2 yr following the red tide damage to the bay scallop population but lacking any transplantation efforts. Consequently, our test of the impact of the adult transplants on the index of scallop settlement represents a comparison of 2 replicate years before and 2 replicate years after transplantation at 1 transplant site in western Bogue Sound and 2 replicate control sites in other sounds. This design permits any effect of the transplants to be identified, unconfounded by natural temporal variability.

Our second means of assessing the effectiveness of the transplantation of pre-spawning adult bay scallops was to evaluate the abundance of newly recruited bay scallops in natural seagrass beds in both western Bogue Sound and in control sites in the 2 other sounds. Sampling of abundance of that year's recruits was achieved using the methods described in Peterson et al. (1989) by suction dredging 40 replicate $0.5 \mathrm{~m}^{2}$ plots at each of the same 5 study sites where spat collectors were also deployed. This sampling was done in the last week of November and the first week of December in all 3 years (1992, 1993, and 1994), thereby repeating precisely the methodology and tim- ing of sampling at these same 5 sites in 1988 and 1989 (although 60 replicate samples were taken at each site in those years). At this time of year, the 0 -yearclass recruits and adult scallops are readily separated by size (Peterson et al. 1989, Peterson \& Summerson 1992), so analyses can be conducted separately on new recruits and the previous year-class adults. This design thereby permits the assessment of the effectiveness of the transplants on bay scallop recruitment to natural seagrass beds and is analogous in design to the test conducted on spat settlement. The design for this assessment of recruitment differed from the design of the settlement bag experiment by including 2 replicate treatment sites in western. Bogue Sound (Emerald Isle and Salter Path) along with the same 2 replicate control sites in other sounds (Yellow Shoal and Banks Bayl and by being extended over 3 yr rather than just 2. Comparisons of temporal change in abundance of scallop recruits between the transplant sites in western Bogue Sound and control sites in Core and Back Sounds allow separation of natural temporal variation from true effects of transplantation. In addition, we also sampled a site in central Bogue Sound (Dog Island), which is not a location where high abundances of bay scallops have traditionally occurred. This site was chosen to provide an indication of the degree to which the limited spatial scale of larval transport isolates the bay scallop population in western Bogue Sound from other populations to the east in Back and Core Sounds

Physical transport of scallop larvae. In addition to evaluating impacts of the adult transplantation, in 1992 we also deployed spat collector bags and sampled bay scallops that settled and survived in them and then later also sampled recruits in natural seagrass beds at the same 9 sites along a transect in the Intracoastal Waterway that spanned our transplant sites, ranging from behind Bogue Inlet to just east of our most easterly transplant site (Fig. 1). Three of the sites for spat collector deployment were the actual receiver sites where transplants were located in 1992 (Marker 40A at Guthrie Point, Marker 36 at Goose Creek, and Marker 31 at Saunders Creek). This contrast was designed to provide a better understanding of the physical transport and source of competent bay scallop larvae in western Bogue Sound. Twenty replicate spat collectors of the identical construction described above were deployed in September and recovered in October 1992 at each site on the same dates as the spat collectors used to evaluate the effectiveness of transplantation. Sampling procedures were also identical. Suction dredging to sample scallops recruited to the natural seagrass beds was done in December on the same dates and using the same methodologies as in the sampling of recruits for evaluation of the results of the 
transpiants. This effort provided information on how bay scallop settlement and recruitment varied as a function of distance from the ocean inlet in the region where transplantation was conducted.

In 1993, 20 replicate spat collector bags were deployed at each of 5 sites within western Bogue Sound to assess spatial patterns in larval settlement in that year. These deployments spanned almost the full range of 1992 deployments along the Intracoastal Waterway channel, due to location of one set at Marker 42 and another at Marker 28 (Fig. 1). On the southern side of western Bogue Sound deployment locations ranged from a site at the Emerald Isle bridge to a site at Long Island to the east (Fig. 1). When combined with the traditional deployment site of Emerald Isle, this site selection represented a suite of 5 sites scattered across western Bogue Sound. No dredge sampling of natural rerruitment into seagrass beds at these 4 supplemental sites was conducted. Deployment and recovery of these supplemental spat collectors occurred on the same days in 1993 as at the other spat collector sites in that year.

To provide a better physical context in which to understand the transport of scallop larvae, physical oceanographic sampling was conducted along the Intracoastal Waterway in autumn 1992. During the period of deployment of the spat collectors and while bay scallop larvae were presumably developing in the water column, we measured vertical profiles of current velocity, water temperature, and salinity at 3 locations along the transect of spat deployment locations (Fig 1). At each location, profiles were collected using an InterOcean S4 electromagnetic current meter that was raised and lowered over the side of a moored boat. Measurements were averaged for 1 to 2 min at 8 to 10 depth levels (depending upon depth) at $0.5 \mathrm{~m}$ increments through the water column. A profile was initiated every $30 \mathrm{~min}$ for a complete semi-diurnal tidal cycle at each sampling location. Full moon occurred on 11 October, and sampling was conducted on 12 (Marker 28), 13 (Marker 36), and 14 (Marker 42) October. In addition, water level, temperature, and salinity data were collected continuously from 8 September to $4 \mathrm{No}$ vermber 1992 using the PSWIMS instrument system (Luettich et al. 1993) from an instrument array moored at the Goose Creek transplant receiver site.

\section{RESULTS}

\section{Testing alternative transplantation techniques}

Our manipulation of flow rates through the holding tanks fed by seawater taken directly from Bogue Sound was effective in altering the dissolved oxygen content of the water in the tanks (Fig. 2). The high-flow treatment successfully retained oxygen concentrations at 7 to $7.5 \mathrm{ppm}$, which were essentially identical to those observed simultaneously in the sound over the 6 h experiment. Oxygen concentrations in the low-flow treatment quickly reached and remained at about 4 ppm for the duration of the experiment, whereas the intermediate-flow treatment exhibited oxygen concentrations of 5.5 to $6.5 \mathrm{ppm}$ (Fig. 2). Water temperature in the sound and in the tanks remained at about $31.8^{\circ} \mathrm{C}$ during the experiment, while the air tompcrature varied from about 30 to $32^{\circ} \mathrm{C}$ (Fig. 2).

Mortality rates of the adult bay scallops after $6 \mathrm{~h}$ varied significantly with holding conditions (ANOVA,
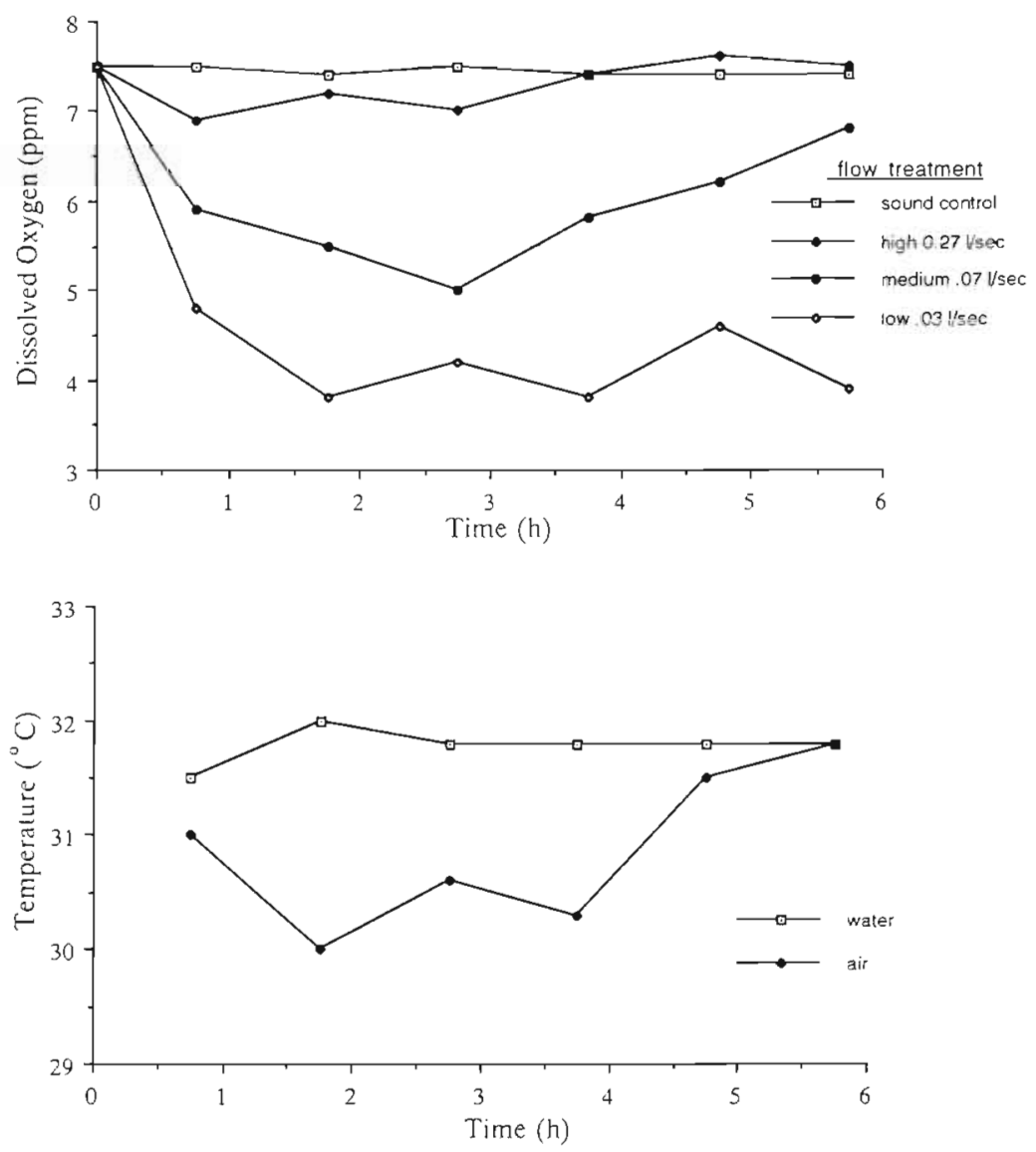

Fig. 2. Results of hourly measurements of oxygen concentration in the sound (control) and in $5 \mathrm{gal}$ (ca 19 I) plastic buckets of 300 adult scallops in each of 3 flow treatments (top panel), stacked over results of hourly measurements of temperature of the water in the sound and in the air during this experiment (bottom panel) 


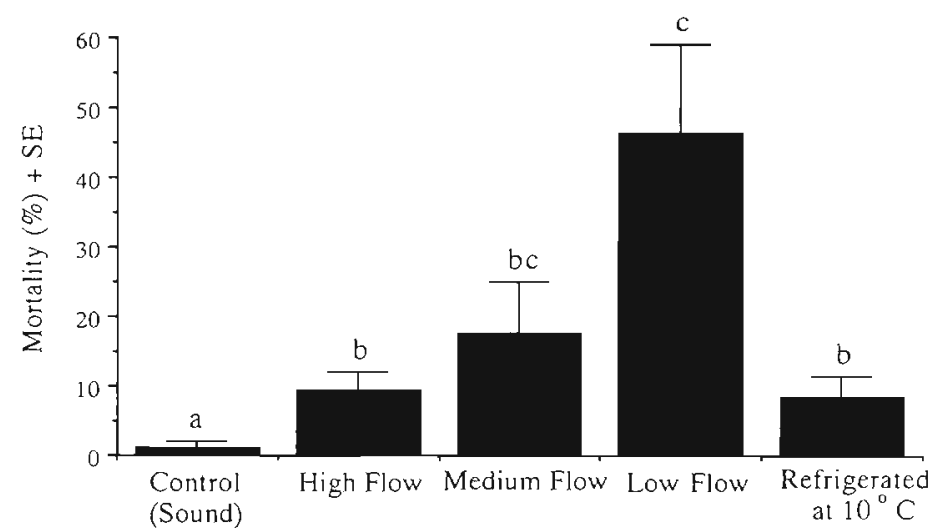

Fig. 3. Argopecten irradians concentricus Say. Average $(+\mathrm{SE} ; \mathrm{n}=2)$ percent mortality of adult bay scallops after $6 \mathrm{~h}$ under each of 5 alternative sets of holding conditions. Letters over each bar indicate those treatment means that differ significantly at $\mathrm{p}<0.05$ in Duncan's test, conducted after a 1-factor ANOVA showed a significant effect of holding treatment experiment, independent of holding time. Air temperatures within the coolers ranged from about 25 to $27^{\circ} \mathrm{C}$, while ambient water temperatures in the sound were about $31^{\circ} \mathrm{C}$ (Fig 4 ).

\section{Fates of scallops after transplantation}

In each year, the numbers of bay scallops removed from the donor site of Oscar Shoal were set at levels such that no more than $3.5 \%$ of the adult scallops present would be taken. This upper limit on numbers of scallops was estimated from mapping the seagrass habitat on Oscar Shoal, calculating its area, and sampling by suction dredge from haphazardly located plots within the seagrass bed. We estimated a total June-July abundance of adult bay scallops over the $180000 \mathrm{~m}^{2}$ of this donor site of $p=0.01$ ). This test was conducted on the 4 th root of the number of dead scallops, a transformation that produced the smallest and a statistically non-significant difference in variance among treatments by Cochran's test. Mortality rate was significantly higher by a factor of between 8 and 45 ( $p<0.05$ in Duncan's test) than the $1 \%$ observed in the controls held in the sound for each of the 4 treatments (Fig 3). Mortality rate varied inversely with flow speed and therefore oxygen concentration in the 3 flow treatments, with a maximum of $46 \%$ in the low-flow treatment and a minimum of $9 \%$ in the high-flow treatment (Fig. 3). Average mortality under refrigeration at $10^{\circ} \mathrm{C}$ was $8.5 \%$. Duncan's test revealed that the difference in scallop mortality between the high-and low-flow treatments was significant $(p<0.05)$, but the medium-flow treatment could not be distinguished from either of the 2 extremes. Mortality in the refrigeration treatment was not significantly different from observed mortality in the low-or medium-flow treatments (Fig. 3). In the experiment assessing the survivorship of adult bay scallops stored out of water in plastic coolers, mortality was negligible and did not vary significantly with duration of storage in the experimental range of 1.75 to $4 \mathrm{~h}$ ( $\mathrm{p}>0.05$ in ANOVA on untransformed counts; Fig. 4). On average about $1.5 \%$ of the scallops died during this
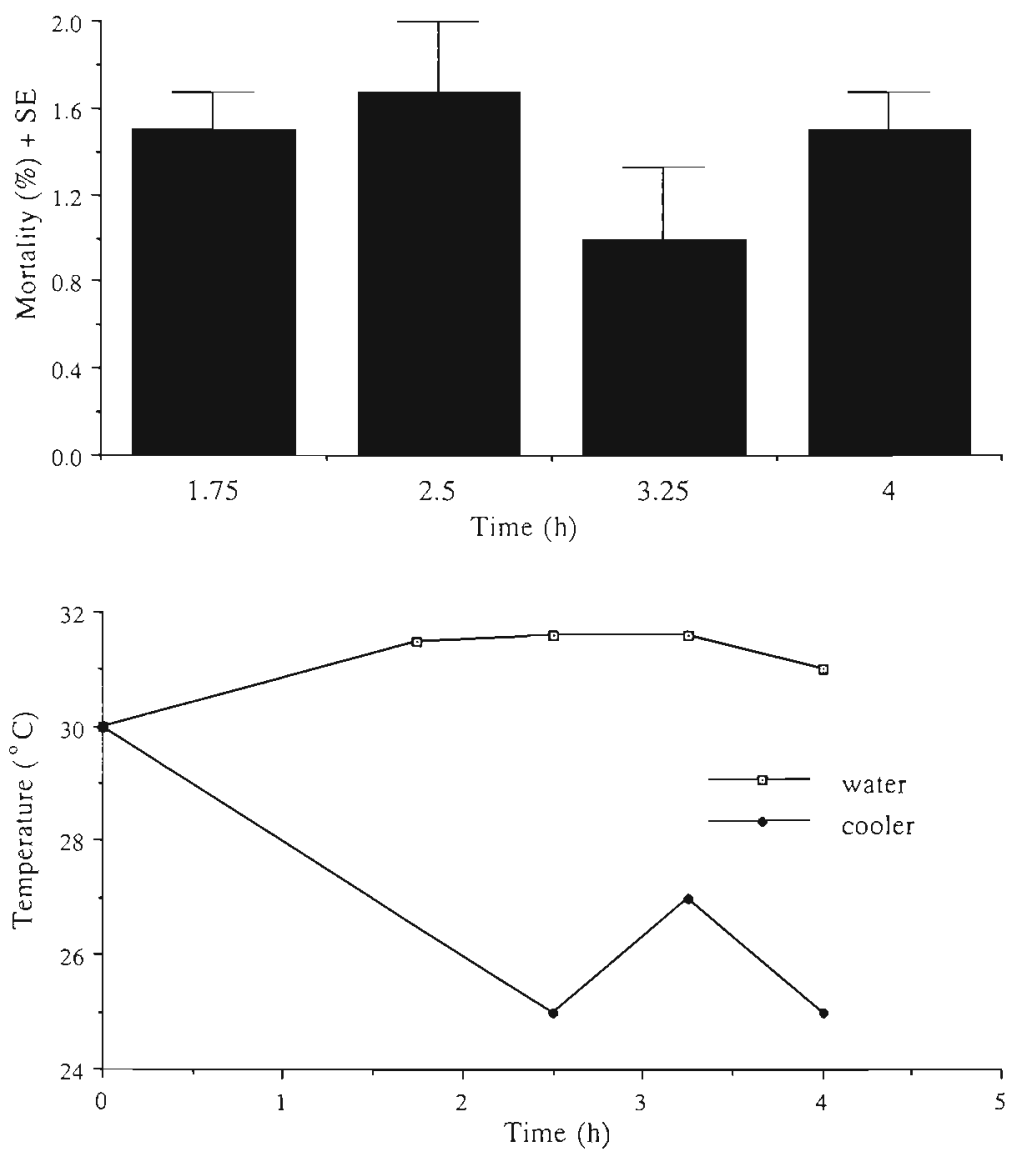

Fig. 4. Argopecten irradians concentricus Say. Average $(+\mathrm{SE} ; \mathrm{n}=2)$ percent mortality of adult bay scallops when held for varying lengths of time out of water inside insulated plastic coolers (top panel), stacked over results of measurements of water temperature in the sound at the site from which the scallops were collected and inside the coolers at intervals during the experiment (bottom panel) 
8973000 in 1992,4170000 in 1993, and 4450000 in 1994. From these, we removed $135000(1.5 \%)$ in 1992 , $100000(2.4 \%)$ in 1993, and $150000(3.4 \%)$ in 1994.

Transplanted scallops survived in all 3 years without any obvious mortality at any of the receiver sites. In 1992, the year when survival of the transplants was quantitatively monitored, densities of transplanted adults remained high at each of the 4 transplant sites in Bogue Sound without any detectable mortality (Fig. 5). Density estimates produced by visual counting of adult bay scallops inside haphazardly positioned $2 \mathrm{~m}^{2}$ sampling quadrats at low tide revealed an immediate increase in abundance of adult bay scallops after completion of the transplants and no subsequent decline, except possibly at Guthrie Point (Fig. 5). Our assessment of the incidence of handling mortality resulting from the transfer itself also revealed negligible mortality during transplantation: $99.8 \%$ of the scallops transplanted into plastic mesh enclosures at each of the receiver sites were alive $2 \mathrm{~d}$ after completion of the transplant. In addition, sampling of the ring of seagrass around the perimeter of the transplant area demonstrated no evidence of emigration of scallops, even on this local scale, from the transplant site (Fig. 5); this was consistent with maintenance of the numbers inside the boundaries of the transplant sites. No analogous sampling of the survivorship of transplanted scallops was conducted in 1993 or 1994, when the transplant sites were chosen in even lower-energy environments.

\section{Effectiveness of the spawner transplants}

Our data on settlement intensity onto spat collectors reveal a pattern of apparent increase in settlement at the 2 control sites in Back and Core Sounds from 1988 and 1989 to 1992 and 1993 (Fig. 6). The settlement results at the one site in western Bogue Sound where settlement was monitored (i.e. Emerald isle) revealed greater temporal variability in bay scallop settlement, with settlement intensity highest in 1989 (Fig. 6). A 2-factor ANOVA performed on 4 th root-transformed counts (which removed heteroscedasticity in Cochran's tests at $p<0.05$ ), revealed significant effects of site, year, and their interaction (all at $\mathrm{p}<0.0011$. However, a pre-planned contrast (Day \& Quinn 1989) of whether the mean settlement was increased after transplants at Emerald Isle relative to the temporal rhange observed at the 2 control sites was non-significant.

Data on recruitment of bay scallops into natural seagrass beds were taken from 2 sites within western Bogue Sound, the same 2 control sites in Back and Core Sounds, and a site in central Bogue Sound. Recruitment into the natural seagrass beds was substantial at all sites except the one in central Bogue Sound, where recruitment was consistently negligible (Fig 7). A 2-factor ANOVA performed on 4th root-transformed counts revealed significant (all at $p<0.001$ ) effects of site, year, and their interaction in this data set, exclud-

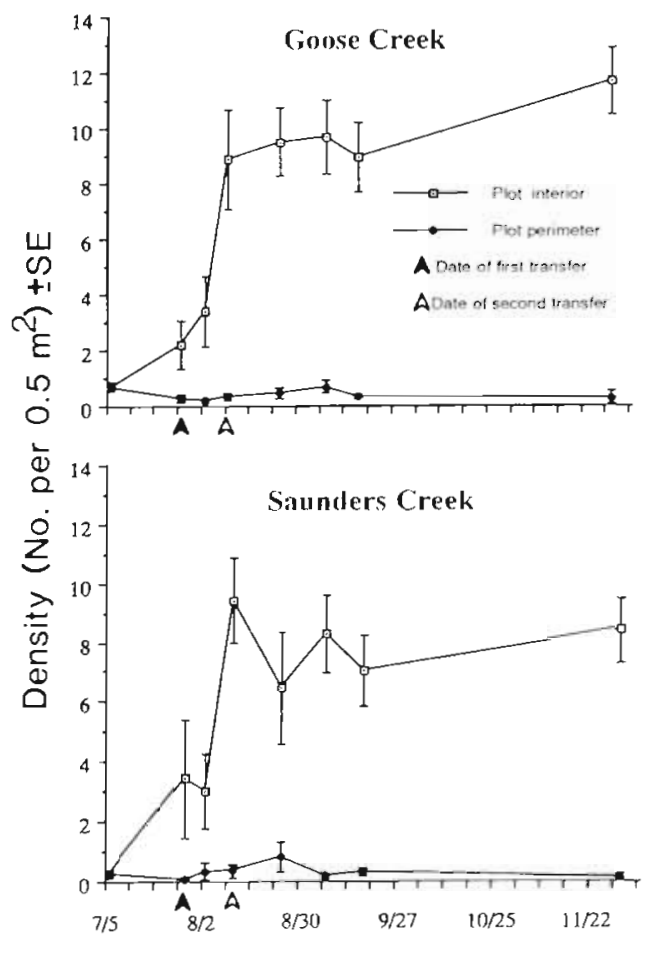

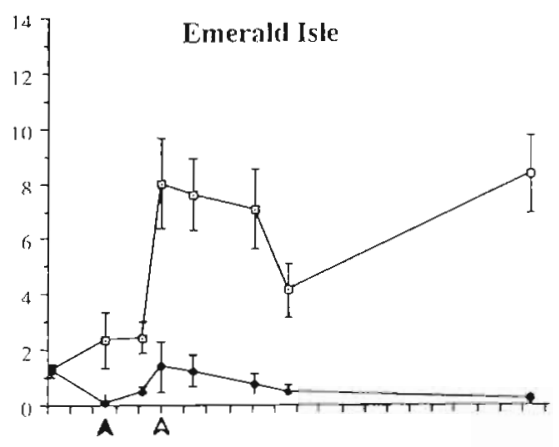

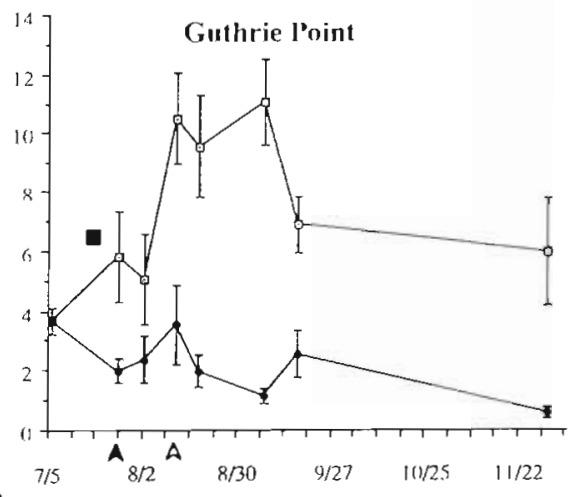

Fig. 5. Argopecten irradians concentricus Say. Temporal changes in average $\left( \pm \mathrm{SE}_{i} n=16\right.$ to 24$)$ densit; of adult bay scallops within the $1200 \mathrm{~m}^{2}$ transplant site and in a perimeter area of the same size surrounding each transplant site for each of the 4 receiver sites in 1992. See Fig. 1 for specific locations of these receiver sites. Dates presented as month/day 


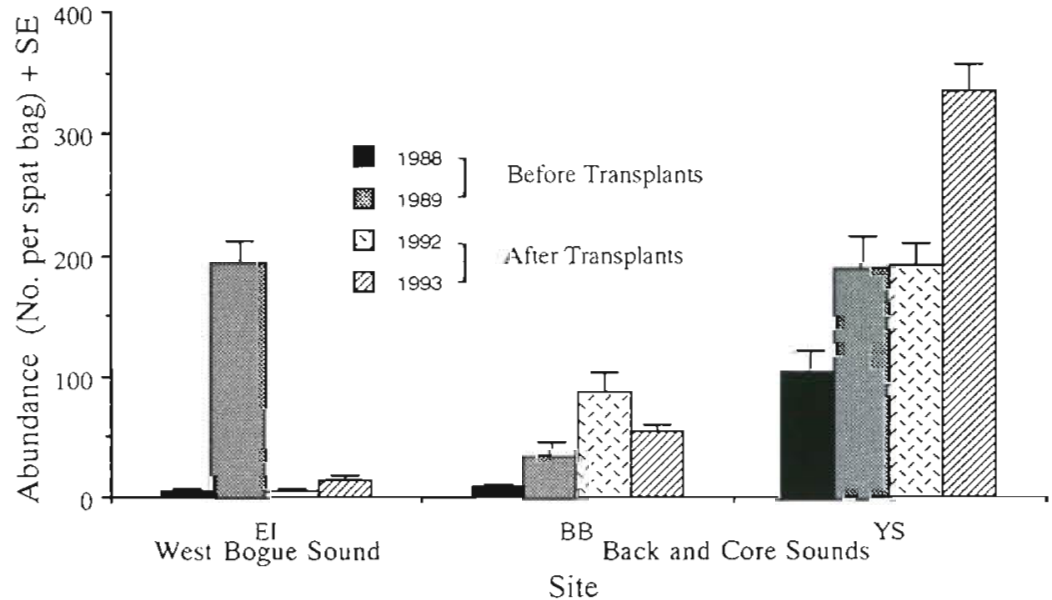

Fig. 6. Argopecten irradians concentricus Say. Average ( $+\mathrm{SE} ; \mathrm{n}=8$ to 20 ) abundance of settled bay scallops per spat collector bag in 2 yr before (without) transplants and in 2 yr after (with) transplants in 1 treatment location in western Bogue Sound (El: Emerald lsle) and in 2 control locations (BB: Banks Bay and YS: Yellow Shoal) where no transplantation occurred

ing the site in central Bogue Sound from analysis (Table 1). A pre-planned contrast on mean numbers of recruits revealed (using methods of Day \& Quinn 1989) that the magnitude of increase in density after transplantation at the sites in western Bogue Sound was significantly ( $p<0.01$ ) greater than the temporal increase observed simultaneously at the 2 control sites that did not receive transplants. From 1988-1989 to 1992-1994, western Bogue Sound sites exhibited a $568 \%$ increase in bay scallop recruitment, while the sites in the control sounds showed a non-significant $34 \%$ increase (Table 2).

Since the suction dredge sampling done in early December also samples adult bay scallops, it is also possible to use the results of this sampling to assess the effect of transplantation on the subsequent generation of adult scallops in natural seagrass beds. For this contrast (Fig. 8), only 2 years (1993 and 1994) represent adults that were produced after transplantation, while the other 3 years represent pre-transplant values. Again, the 2-factor ANOVA performed on 4 th root-transformed counts revealed significant ( $p<0.001$ ) effects of site, year, and their interaction, again excluding from analysis the central Bogue Sound site of Dog Island (Table 3). An analogous contrast of means (by the Day \& Quinn
1989 methods) revealed that the average increase in adult density from 1988, 1989, and 1992 to 1993-1994 after transplantation at the 2 western Bogue Sound sites was significantly ( $p<0.001)$ greater than the average change in adult bay scallop density at the 2 control sites in that same period. From 1988, 1989, and 1992 to 19931994, western Bogue Sound sites exhibited a $258 \%$ increase in density of adult bay scallops, while the sites in the control sounds showed a non-significant $8 \%$ increase (Table 4 ).

\section{Physical transport of scallop larvae}

The pattern of bay scallop settlement onto spat collectors and the pattern of recruitment of bay scallops to the natural seagrass beds at those same 9 sites along the Intracoastal Waterway transect established in 1992 were similar (Fig. 9). Both settlement and recruitment were highest at the Marker 42 location, the one second from the westernmost (Fig. 1). The settlement data showed higher recruitment at the 3 westernmost locations with declining intensity to the

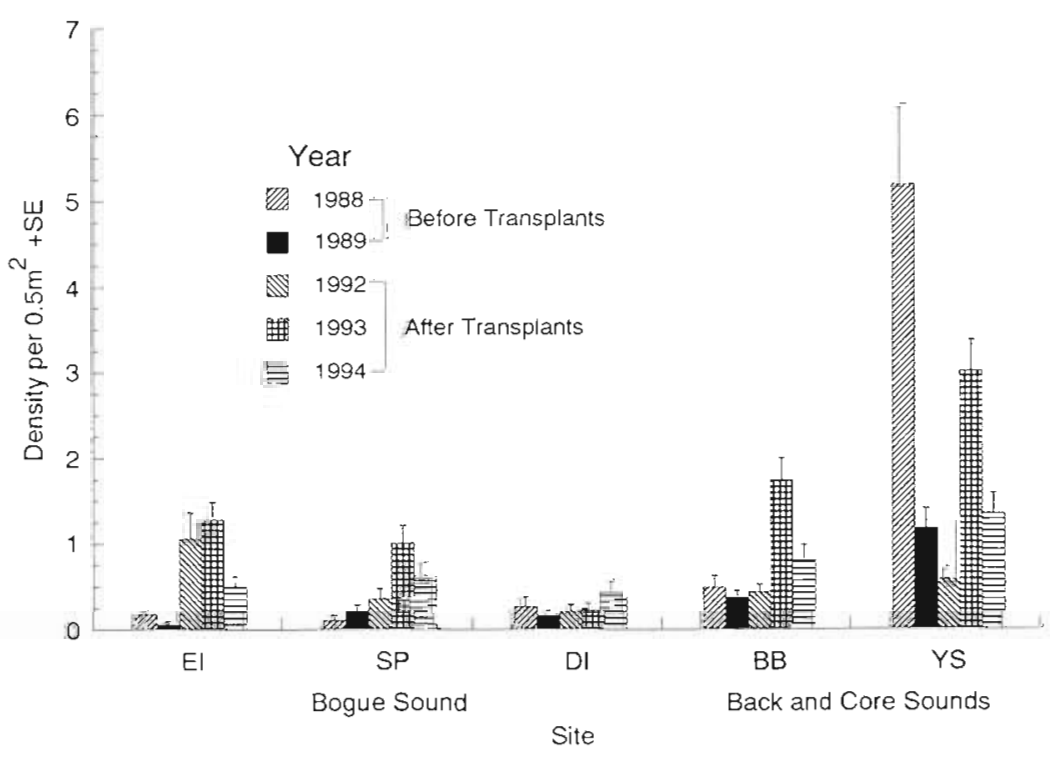

Fig. 7. Argopecten irradians concentricus Say. Average ( $+\mathrm{SE} ; \mathrm{n}=35$ to 61$)$ density of newly recruited bay scallops in natural seagrass beds as measured in early December after cessation of recruitment in each of 2 yr before (without) transplants and in each of $3 \mathrm{yr}$ after (with) transplants in 2 treatment locations in western Bogue Sound (EI: Emerald Island and SP: Salter Path), in 2 control locations in other sounds where no transplantation occurred (BB: Banks Bay and YS: Yellow Shoal), and in 1 location in central Bogue Sound outside the influence of tidal forcing from Bogue Inlet (DI: Dog Island) 
Table 1. Argopecten irradians concentricus Say. Results of ANOVA testing whether recruitment of bay scallops, as measured by counting juveniles in suction dredge samples in December, varied with site, year, or their interaction. Tests were conducted on 4th root-transformed counts, which homogenized variances in Cochran's test at $\alpha=0.05$. Significance $(\cdots p<0.001)$ comes from 2 -factor ANOVA with site and year as fixed, crossed factors. df: degrees of freedom; MS: mean square; $F$ : variance ratio tested

\begin{tabular}{|lrrrr|}
\hline Source of variation & df & MS & $F$ & Sig \\
\hline Site $(S)$ & 3 & 10.00 & 35.4 & $\ldots$ \\
Year $(Y)$ & 4 & 7.87 & 28.9 & $\ldots$ \\
S $\times$ Y interaction & 12 & 1.25 & 4.4 & $\ldots$ \\
Error & 928 & 0.282 & & \\
\hline
\end{tabular}

Table 3. Argopecten irradians concentricus Say. Results of ANOVA testing whether adult bay scallop densities, as medsured by counting adults in suction dredge samples in December, vatied with site, year, or their interaction. Tests were conducted on 4 th root-transformed counts, which homogenized variances in Cochran's test at $\alpha=0.05$. Significance $(\cdots p<0.001$ ) comes from 2 -factor ANOVA with site and year as fixed, crossed factors df: degrees of freedom; MS: mean square; $F$ : variance ratio tested

\begin{tabular}{|lrrrr|}
\hline Source of variation & di & MS & $F$ & Sig \\
\hline Site $(S)$ & - & 17.7 & 89.2 & $\ldots$ \\
Year $(Y)$ & 4 & 14.7 & 74.1 & $\ldots$ \\
SXYinteraction & 12 & 4.2 & 21.2 & $\cdots$ \\
Error & 869 & 0.198 & \\
\hline
\end{tabular}

east (Fig. 9). The recruitment data differed somewhat in that recruitment at the eastern end of the transect was somewhat greater than would have been expected from the settlement pattern (Fig 9). A Pearson product-moment correlation on these untransformed means was significant $(p<0.05)$ when performed on only the 9 sites along the transect on the Intracoastal Waterway. When repeated using also the Emerald Isle site on the southern side of western Bogue Sound, this relationship disappeared ( $\mathrm{p}>$ 0.20). In 1993, when only 5 spat collector sites were used in western Bogue Sound and no sampling of recruitment into natural seagrass beds was conducted except at the traditional Emerald Isle site (Fig. 1), density of scallop settlers was uniform $(p>0.40$ in a 1-factor ANOVA) among sites, ranging only from 9.7 at Marker 42 and 12.2 at Marker 28 to 13.3 at Long Island and 15.6 settlers per bag at the Emerald Isle bridge site. No spat collectors were deployed in 1994

The continuous water level measurements made at Goose Creek (Fig. 10) show that the

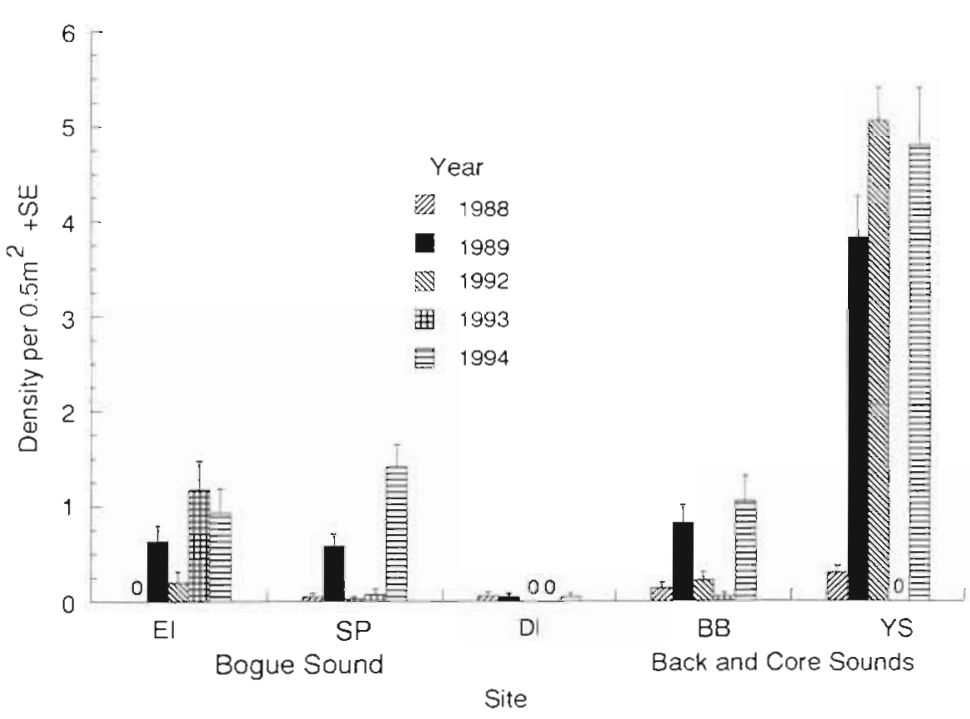

Fig. 8. Argopecten irradians concentricus Say. Average $1+\mathrm{SE} ; \mathrm{n}=20$ to 61) density of adult bay scallops in the same samples described for Fig. 7. Replication is lower for some adult data sets because any sample that fell withun any part of the inner or outer perimeter of 1 of the 4 specific transplant sites was excluded from our estimate of adult density to avoid bias from inclusion of imported adult scallops

Table 2. Argopecten irradians concentricus Say. Bay scallop recruitment as estimated by suction dredgıng in December. Temporal patterns of recovery after the 1987-1988 red tide outbreak in western Bogue Sound, where adult spawner transplants were conducted in 1992, 1993, and 1994, as compared to 2 control sites in Back and Core Sounds where no transplants took place

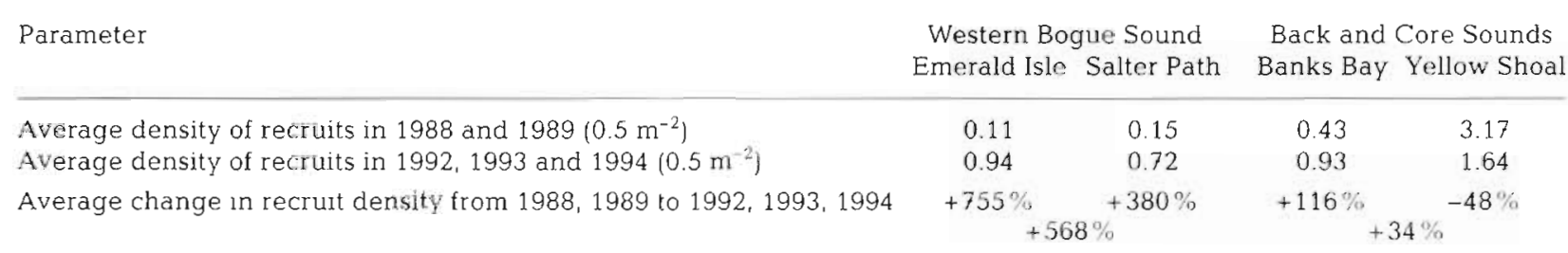


Table 4. Argopecten irradians concentricus Say. Bay scallop recovery in adult density as measured by suction dredge in December Transplants of spawners were made into western Bogue Sound in 1992 and 1993 with adults from that spawn appearing in vecember 1993 and December 1994 data

\begin{tabular}{|c|c|c|c|c|}
\hline Parameter & $\begin{array}{l}\text { Western Bog } \\
\text { Emerald Isle }\end{array}$ & $\begin{array}{l}\text { Tue Sound } \\
\text { Salter Path }\end{array}$ & $\begin{array}{l}\text { Back and } \\
\text { Banks Bay }\end{array}$ & $\begin{array}{l}\text { Core Sounds } \\
\text { Yellow Shoal }\end{array}$ \\
\hline $\begin{array}{l}\text { Average adult density in } 1988,1989,1992\left(0.5 \mathrm{~m}^{-2}\right) \\
\text { Average adult density in } 1993 \text { and } 1994\left(0.5 \mathrm{~m}^{-2}\right)\end{array}$ & $\begin{array}{l}0.28 \\
1.06\end{array}$ & $\begin{array}{l}0.22 \\
0.75\end{array}$ & $\begin{array}{l}0.40 \\
0.55\end{array}$ & $\begin{array}{l}3.06 \\
2.40\end{array}$ \\
\hline Average change in adult density from $1988,1989,1992$ to 1993,1994 & \multicolumn{2}{|c|}{$+258 \%$} & $+38^{\circ}$ & $+8 \%$ \\
\hline
\end{tabular}

system is characterized by a semi-diurnal variation of approximately $30 \mathrm{~cm}$ due to forcing from the coastal ocean. Energy is also present at the diurnal frequency and has the effect of accentuating every second high and low associated with the semi-diurnal tide as well as creating a fortnightly variation in water level. The tidal fluctuations are superimposed upon non-tidal fluctuations in water level of as much as $30 \mathrm{~cm}$ (Fig. 10). The largest of these occurred from 17 to 26 September and suggests a net transport of shelf water into the sound

Although vertical profile measurements were made on 3 different days, the water level record in Fig 10 suggests that these days (12 to 14 October) were not atypical. Therefore, we compare the results of all 3 days directly and use them to characterize the tidal transport in the main channel of the sound, the Intracoastal Waterway. Maximum alongchannel velocities were 40 to $50 \mathrm{~cm} \mathrm{~s}^{-1}$ at Marker 42 closest to Bogue Inlet, 20 to $30 \mathrm{~cm} \mathrm{~s}^{-1}$ at Marker 36, and less than $10 \mathrm{~cm} \mathrm{~s}{ }^{1}$ at Marker 28 furthest to the east. The velocities measured at Marker 28 were not much larger than the expected accuracy of our measurement instrument and methodology. No significant crosschannel velocities were detected at any site. Temperature and salinity profiles (not shown) were essentially uniform with depth at all sites throughout the tidal cycle. By integrating the along-channel velocities through half a tidal cycle at each site, it is possible to calculate the tidal excursion or maximum travel distance of a hypothetical free-drifting larva, assuming it was subjected for the full half cycle to the flows prevailing at that site. In reality, of course, transport would carry it to different sites along the channel where different velocities would prevail, but this calculation serves to translate observed velocity records into a realistic excursion scale for each site. These calculations suggest a maximum transport distance of about 5, 2.5, and $0.5 \mathrm{~km}$ at the 3 sites. Flux calculations made by integrating the along-channel
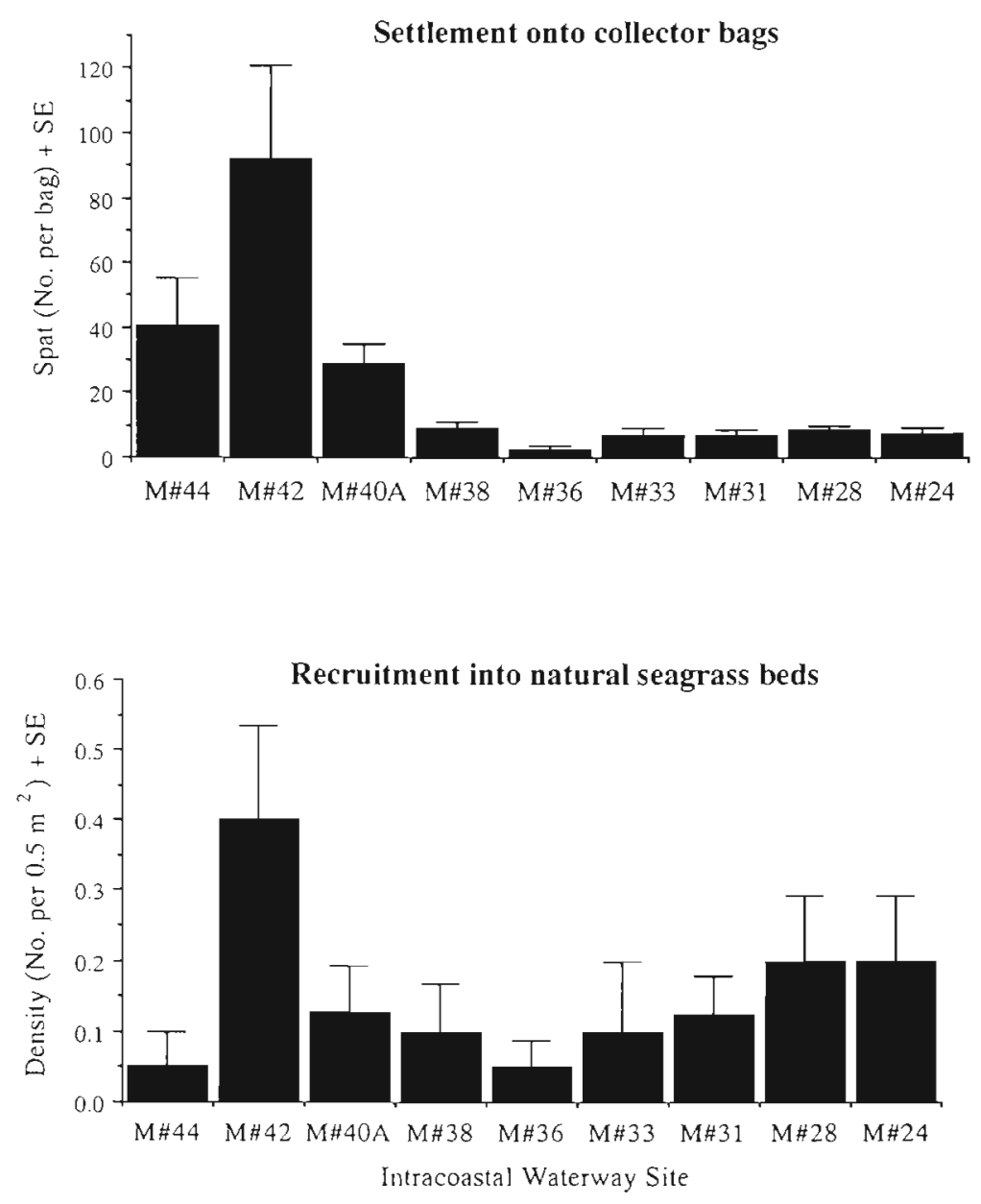

Fig. 9. Argopecten irradians concentricus Say. Average (+SE; $\mathrm{n}=15$ to 20) number of settled bay scallops per spat collector bag (top panel), assessed at the end of October, and average ( $+\mathrm{SE} ; \mathrm{n}=20$ to 40 ) density of recruited bay scallops in natural seagrass beds, assessed in early December, at sites arranged along a transect from behind Bogue lnlet eastward into Bogue Sound. See map in Fig. 1 for specific locations 


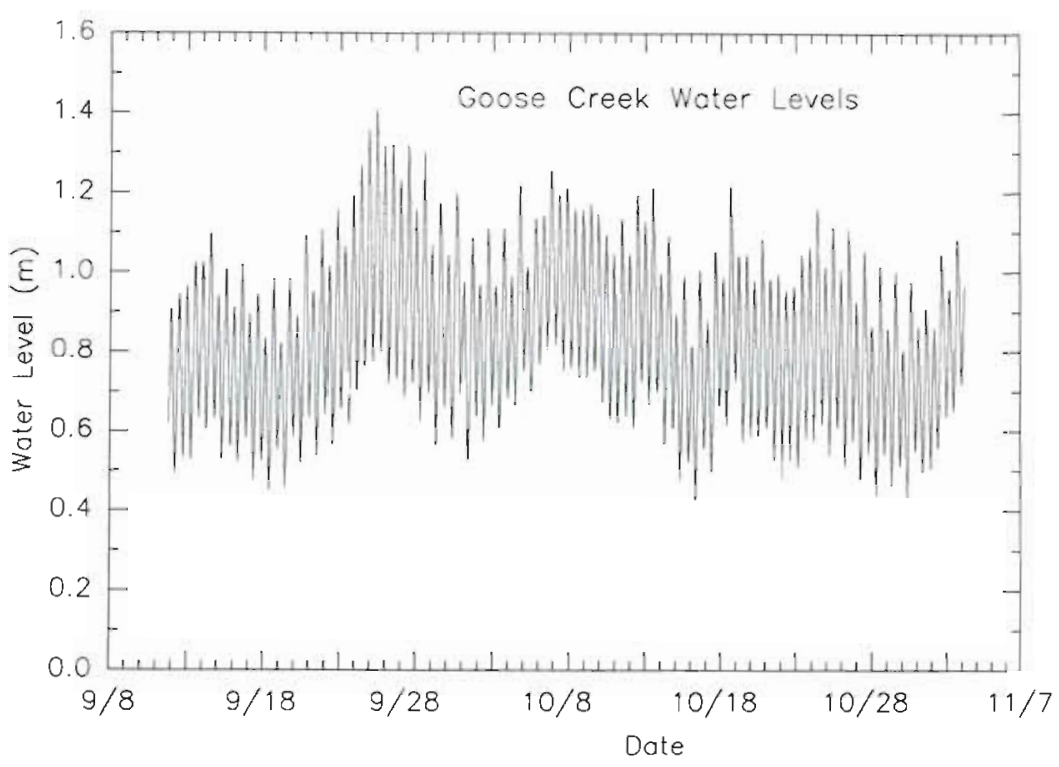

Fig. 10. Time series of continuous water level measurements made from an instrument mooring at the Goose Creek transplant site in autumn 1992. See Fig. 1 for location of Goose Creek. Dates presented as month/day not seek to identify the limits to this process because the $4 \mathrm{~h}$ period sufficed for our needs. In winter, when temperatures are cooler and metabolic rates are reduced, scallops may be even less susceptible to stress and mortality from handling and transport. Further tests of transplant methods might include evaluating the effects of season and temperature if transplants over greater distances are contemplated. If bay scallop populations are indeed recruitment-limited within water bodies on the scale of sounds, longer-distance transplants may be a reasonable means of restoring bay scallops to localities in many areas where scallops have virtually disappeared (e.g. Tettelbach \& Wenczel 1993) but where seagrass habitat seems adequate. However, the very isolation of bay scallop populations that may prevent nat- velocity profiles across the channel crosssection, assuming uniform flow across the channel and using measurements of bank-to-bank bathymetry taken separately at each station for the cross-sectional area, indicate a decrease in maximum flux along the channel from 100 to $150 \mathrm{~m}^{3} \mathrm{~s}^{-1}$ at Marker 42 to approximately $25 \mathrm{~m}^{3} \mathrm{~s}^{-1}$ at Marker 36 (Fig. 11). At Marker 28 , the flux appears to be $180^{\circ}$ out of phase with the the other 2 locations. This pattern implies that the water at Marker 28 was draining at this time primarily through Beaufort Inlet at the eastern end rather than Bogue Inlet at the western end of Bogue Sound.

\section{DISCUSSION}

Despite the physiological sensitivity of bay scallops (Belding 1910, Gutsell 1930. Mercaldo \& Rhodes 1982 , Tettelbach et al. 1985), we were able to find a means of transporting adult bay scallops during the daytime heat of summer that caused negligible mortality during travel times of up to $4 \mathrm{~h}$ (Fig. 4). Given the absence of any trend of increasing mortality with longer holding time in these experiments, it is conceivable that the scallops can survive much longer periods of transport. We did
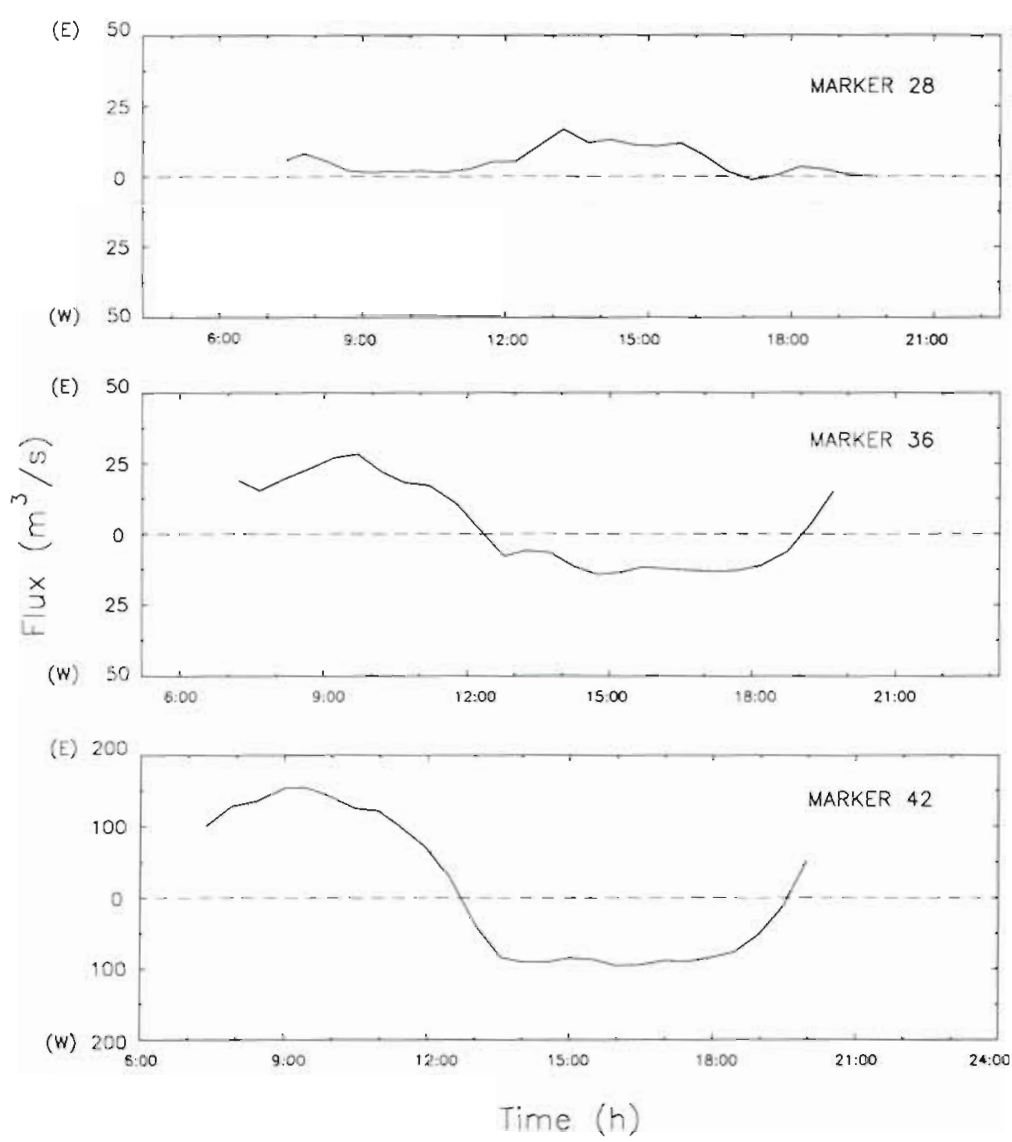

Fig. 11. Total water flux during a complete tidal cycle through the channel of the Intracoastal Waterway computed from vertical. velocity profiles and crosschannel bathymetry at each of 3 sites in western Bogue Sound. See Fig. 1 for the locations of these sites 
ural larval transport from distant populations from serving to repopulate depleted scallop grounds also implies that local genetic adaptation may have developed, rendering transplanted scallops less well adapted to survive in a new locality. The evident geographic variation in spawning times (e.g. Belding 1910, Gutsell 1930, Sastry 1966, Bricelj et al. 1987) represents a particularly critical concern in evaluating the likely fitness of imported scallops

In the course of identifying a means of transplanting adult bay scallops in summer with acceptably low handling mortality, we collected data on 1 additional type of physiological stress on bay scallops, the impact of low oxygen. As oxygen concentrations in our experiment fell below 7 ppm, bay scallop mortality rose. At around 4 ppm, mortality approached 50\% during a period of $6 \mathrm{~h}$ (Fig. 3). Since oxygen concentration covaried with flow rate and other unmeasured variables in our experimental regime, these data do not represent a pure, unconfounded test of the effects of oxygen reduction on adult bay scallops. Nevertheless, the increase in mortality of these adult bay scallops coincides with the decline in oxygen concentration to levels that define hypoxia and are typically considered by water quality managers capable of degrading aquatic communities

The impact of our transplants of adult scallops into western Bogue Sound during summer 1992, 1993, and 1994 on the recruitment of bay scallops into seagrass habitat was clear. Recruitment into natural seagrass beds showed a $568 \%$ increase in western Bogue Sound from 1988-1989 to 1992-1994 after adult scallop transplantation, a change substantially greater than the $34 \%$ increase observed in the control sounds over this same time period (Table 2). In order to be conservative, we tested the significance of this effect on recruitment by analyzing the actual difference in numbers of recruits rather than the percentage changes: these differential increases in recruitment after transplantation were significantly greater at the transplant sites than in the control sounds. The effect on recruitment is also evident when adult scallop numbers are examined: adult bay scallops in 1993 and 1994, resulting from the recruitment in 1992 and 1993, were enhanced in western Bogue Sound by $258 \%$ over levels observed in 1988, 1989, and 1992, while adult densities remained unchanged ( $8 \%$ estimated increase) in the 2 control sites over this same time period (Table 4).

Since the number of recruits in natural bottom habitats represents the variable of most direct relevance to the actual population in nature, it seems appropriate to conclude that recruitment was enhanced and recovery thereby promoted by transplantation of adult spawners into the depleted water basin of western Bogue Sound. However, our inability to demonstrate a strict corre- spondence between these recruitment data measured by sampling the natural seagrass habitat in December (Fig. 7) and the settlement data collected by counting recruits on spat bags (Fig. 6) raises some concern. In our past studies of bay scallop recruitment (Ambrose et al. 1992, Peterson \& Summerson 1992), settlement onto spat bags and recruitment into natural seagrass habitat at that same site were generally but not always well correlated. Breakdown of this correlation can occur through numerous potential processes, especially through differential rates of post-settlement mortality, which is driven mostly by predation (e.g. Peterson 1990, Prescott 1990, Eggleston et al. 1992). We cannot provide an explanation for the breakdown of this relationship in our data; however, it is important to recognize that the test of recruitment is achieved through a more powerful design than the test of settlement, with 2, not just 1, treatment sites and with 3, not just 2, years of response data. High temporal variability in settlement of bay scallops at the Emerald Isle site makes testing of effects of transplantation on settlement difficult. Ironically, those species that exhibit great variability in recruitment among years and among potentially suitable sites, like most scallop species (see Orensanz 1986), are the ones in which recruitment limitation is most likely, yet that very variability limits power to detect the recruitment limitation in any formal rigorous evaluation. With just 1 treatment site (Emerald Isle) in our spat collector design, the intrinsic variability in scallop recruitment may be the cause of the failure to exhibit significant enhancement of settlers. The absence of a match between settlement onto spat collector bags and recruitment into natural seagrass habitat prevents us from confirming that the enhanced scallop recruitment after transplantation of adults into Bogue Sound was a consequence of enhancement in the abundance of larval scallops. There is, therefore, a possibility that we achieved the right prediction about the consequences of spawner transplants for the wrong reason (Dayton 1973).

Examination of physical data along with data on settlement and recruitment of scallops along a transect in the Intracoastal Waterway provides insight into the question of whether bay scallops are indeed recruitment-limited at traditional scallop grounds within estuarine basins and thus whether the success of our transplants in promoting recruitment was achieved by enhancing larval abundances. The virtual absence of any vertical shear or stratification in water temperature or salinity at any of the 3 sites at any time during the tidal cycle suggests that flow in this channel can be viewed simply as 1-dimensional plug flow. Calculations of along-channel flux at each site (Fig. 11) reveal that our easternmost transplant site in 1992 lies close to the hydrographic center of Bogue Sound as defined by 
the dominant semi-diumal tide. While we have no data on net long-term transport at this site, it is clearly not participating in active water mass exchange with a significant portion of the western sound at the tidal frequency. If there is no net long-term transport at subtidal frequencies during the period of larval life of the scallops, this Dog Island site would indeed be isolated from the treatment sites in western Bogue Sound because it lies outside the region directly forced by tidal excursion from Bogue Inlet and in the region affected by Beaufort Inlet at the eastern end of Bogue Sound. Residual circulation forced by wind events could occasionally transport bay scallop larvae from the western Bogue Sound to Dog Island, but wind-generated currents are low compared to observed tidal currents.

The 1992 pattern of greatest settlement of bay scallops onto spat collectors at the end of the transect closest to Bogue Inlet (Fig. 9) may imply that the bay scallop larvae come from a source at that end of the gradient, either because they develop offshore on the shelf or within the sound in higher-salinity waters closest to the inlet. Alternatively, this pattern observed in 1992 may reflect the consequences of a net long-term transport of the water mass containing the developing scallop larvae westward, creating a concentration of competent settlers at the western end of Bogue Sound. Our physical data do not allow discrimination between these 2 alternative explanations. This spatial pattern of settlement in 1992 is consistent in either case with the hypothesis that western Bogue Sound is sufficiently isolated hydrographically from the closest bay scallop population in Back Sound on the time scales of relevance to larval duration (5 to $12 \mathrm{~d}$; Castagna \& Duggan 1971, Castagna 1975) that it is appropriate to manage the fishery by hydrographic subpopulations and not as a metapopulation.

Although the limited deployment of spat collectors in western Bogue Sound in 1993 failed to reveal any trend in settlement with distance eastward, the virtual absence of recruitment of scallops to the site at Dog Island near the middle of Bogue Sound was repeated. Thus, the spatial information on bay scallop recruitment in Bogue Sound on a larger scale consistent with the hydrography defined by tidal excursion implies that the population is recruitment-limited as areas become hydrographically separated from concentrations of adult spawners. This spatial relationship thus is consistent with our interpretation that the spawner transplant succeeded in enhancing recruitment of bay scallops in 1992 to 1994 in western Bogue Sound because of its effectiveness in subsidizing larval abundance, even though the absence of a relationship between settlement data on spat collectors and recruitment data from natural seagrass beds prevented us from unequivocal establishment of the mechanism by which the transplants succeeded.

The success of this restoration of bay scallops and its low cost suggest that the technique of transplanting pre-spawning adult scallops might be applied elsewhere within the bay scallop's biogeographic range where populations of this species have disappeared. Wherever the seagrass habitat seems adequate and where historical data show abundant bay scallops, it would be appropriate for shellfishery managers to consider application of this restoration option. This may require long-distance interstate transport of bay scallops, requiring transport times in excess of the 4 to $6 \mathrm{~h}$ that we tested, so additional trials of methods to minimize mortality of this physiologically sensitive species would be required. Furthermore, we did not conduct tests of just what the most effective density should be to insure maximal fertilization of scallop eggs. As suggested by Levitan et al. (1992) for some sea urchins, failure to achieve adult densities sufficient to produce fertilization for this external fertilizer may be the most important process that can limit successful recruitment. We simply do not know. In addition, there are unanswered questions about whether transplants would be properly adapted in spawning seasonality (e.g Bricelj et al. 1987), thereby defeating their purpose. Despite the continuing uncertainties that require further research, results of our test of the effectiveness of adult transplantation at promoting restoration of a bay scallop population are sufficiently encouraging that this technique may be appropriate for application to other degraded ecosystems, such as perhaps to Barnegat Bay and Little Egg Harbor in New Jersey, USA, Chincoteague Bay in Virginia, USA, and several lagoons on the west coast of Florida. Importation of spawners may prove effective only if limited to use of adults from geographically close populations so as to maximize likelihood of genetic similarity. Locally collected juveniles may need to be spawned and cultured in a shellfish hatchery and nursery to provide a genetically adapted spawner stock if no nearby sources of adults exist. Independent of the choice of restoration technique, detection of recruitment limitation has importance not only to scientists interested in how natural populations function but also to those charged with resource management or restoration.

Acknowledgements. We appreciate the field and laboratory assistance provided by J. Allen, T. Andacht, G. Bath, J. E. Byers, E. Conklin, C. Donahue, W. Ellington, W. Falls, A. Gallagher, G. Grissom, A. R. Hall, J. T Ham, N. Hendricks, R. Herbert, P. Hunt, K. Lally, L. Kellogg. B. Konar, M. Krause, H. Lenihan, G. McQuilkin, N. McCall, F. Micheli, S. Micheli, E. Orlando, E. Oberdoerster, J. Reisenweber, D. Rittschof, G. W. Safrit, Jr, E. Seeber, P. Wyrick. We thank W. R. Geyer and L. Rosenfeld for helpful discussions of physical dynamics. Financial support came from the North Carolina General Assembly 
and NOAA NMFS through the Cooperative Institute of Fisheries Oceanography and from the U.S. Environmental Protection Agency in its Near Coastal Waters Program through the University of North Carolina's Water Resources Research Institute on behalf of the Albemarle/Pamlico Estuarine Study.

\section{LITERATURE CITED}

Ambrose WG Jr, Peterson CH, Summerson HC, Lin J (1992) Experimental tests of factors affecting recruitment of bay scallops (Argopecten irradians) to spat collectors. Aquaculture 108:67-86

Belding DL (1910) A report upon the scallop fishery of Massachusetts. Commonwealth of Massachusetts, Boston

Bricelj VM, Epp J, Malouf RE (1987) Intraspecific variation in reproductive and somatic growth cycles of bay scallops Argopecten irradians. Mar Ecol Prog Ser 36:123-137

Butman CA (1987) Larval settlement of soft-sediment invertebrates: the spatial scales of patterns explained by active habitat selection and the emerging role of hydrodynamic processes. Oceanogi mar Biol A Rev 25:113-165

Castagna M (1975) Culture of the bay scallop. Argopecten irradians, in Virginia. Mar Fish Rev 37:19-24

Castagna M. Duggan W (1971) Rearing the bay scallop Argopecten irradians. Proc natl Shellfish Ass 61:80-85

Day RW, Quinn GP (1989) Comparisons of treatments after an analysis of variance in ecology. Ecol Monogr 59:433-463

Dayton PK (1973) Two cases of resource partitioning in an intertidal community: making the right prediction for the wrong reason. Am Nat 107:662-670

Doherty P, Fowler T (1994) An empirical test of recruitment limitation in a coral reef fish. Science 263:935-939

Doherty PJ, Williams D McB (1988) The replenishment of coral reef fish populations. Oceanogr mar Biol A Rev 26: $487-551$

Duggan WP (1973) Growth and survival of the bay scallop, Argopecten irradians, at various locations in the water column and at various densities. Proc natl Shellfish Ass 63:68-71

Eckman JE (1987) The role of eelgrass hydrodynamics in recruitment, growth and survival of Argopecten irradians (L.) and Anomia simplex (D'Orbigny). J exp mar Biol Ecol 106:165-191

Eggleston DB, Lipcius RM, Hines AH (1992) Density-dependent predation by blue crabs upon infaunal clam species with contrasting distribution and abundance patterns. Mar Ecol Prog Ser 85:55-68

Gaines S, Roughgarden J (1985) Larval settlement rate: a leading determinant of structure in an ecological community of the marine intertidal zone. Proc natl Acad Sci USA 82:3707-3711

Gutsell JS (1930) Natural history of the bay scallop. Bull US Bur Fish 46:569-632

Irlandi EA (1994) Large- and small-scale effects of habitat structure on rates of predation: how percent coverage of seagrass affects rates of predation and siphon-nipping on an infaunal bivalve. Oecologia 98:176-183

Jordan WR III, Gilpin GE, Aber JD (1990) Restoration ecology: a synthetic approach to ecological research. Cambridge Univ Press, New York

Kassner J, Malouf RE (1982) An evaluation of 'spawner transplants' as a management tool in Long Island's hard clam fishery. J Shellfish Res 2: 165-172

This article was presented by K. Sherman (Senior Editorial Advisor), Narragansett, Rhode Island, USA
Levitan DR, Sewell MA, Chia F (1992) How distribution and abundance influence fertilization success in the sea urchin Strongylocentrotus franciscanus. Ecology 73:248-254

Luettich RA Jr, Kirby-Smith WW. Hunnings W (1993) PSWIMS, a profiling instrument system for remote physical and chemical measurements in shallow water. Estuaries 16:190-197

Mercaldo RS, Rhodes EW (1982) Influence of reduced salinity on the Atlantic bay scallop Argopecten irradians (Lamarck) at various temperatures. J Shellfish Res 2: $177-181$

Orensanz JM (1986) Size, environment, and density: the regulation of a scallop stock and its management implications. Can Spec Publ Fish Aquat Sci 92:195-227

Peterson $\mathrm{CH}$ (1990) On the role of ecological experimentation in resource management: managing fisheries through mechanistic understanding of predator feeding behavior. In: Hughes RN (ed) Behavioural mechanisms of food selection. Springer-Verlag, Berlin, p 821-846

Peterson CH, Summerson HC (1992) Basin-scale coherence of population dynamics of an exploited marine invertebrate, the bay scallop: implications of recruitment limitation. Mar Ecol Prog Ser 90:257-272

Peterson CH, Summerson HC, Fegley SR, Prescott RC (1989) Timing, intensity and sources of autumn mortality of adult bay scallops Argopecten irradians concentricus Say. J exp mar Biol Ecol 127:121-140

Prescott RC (1990) Sources of predatory mortality in the bay scallop Argopecten irradians (Lamarck): interaction with seagrass and epibiotic coverage. J exp mar Biol Ecol 144: $63-83$

Sammarco PW, Andrews JC (1989) The HELIX experiment: differential localized dispersal and recruitment patterns in Great Barrier Reef corals. Limnol Oceanogr 34:896-912

Sastry AN (1966) Temperature effects in reproduction of the bay scallop, Argopecten irradians Lamarck. Biol Bull 130: $118-134$

Summerson HC, Peterson CH (1990) Recruitment failure of the bay scallop, Argopecten irradians concentricus, during the first red tide, Ptychodiscus brevis, outbreak recorded in North Carolina. Estuaries 13:322-331

Tester PA, Stumpf RP, Vukovich FM, Fowler PK, Turner JT (1991) An expatriate red tide bloom: transport, distribution, and persistence. Limnol Oceanogr 36:1053-1061

Tettelbach ST, Auster PJ, Rhodes EW, Widman JC (1985) A mass mortality of northern bay scallops, Argopecten irradians irradians, following a severe spring rainstorm. Veliger 27:381-385

Tettelbach ST, Wenczel P (1993) Reseeding efforts and the status of bay scallop Argopecten irradians (Lamarck, 1819) populations in New York following the occurrence of 'brown tide' algal blooms. J Shellfish Res 12:423-431

Underwood AJ, Denley EJ (1984) Paradigms, explanations and generalizations in models for the structure of intertidal communities on rocky shores. In: Strong DR Jr, Simberloff D, Abele LG. Thistle AB (eds) Ecological communities: conceptual issues and the evidence. Princeton University Press, Princeton, p 151-180

Underwood AJ, Fairweather PG (1989) Supply-side ecology and benthic marine assemblages. Trends Ecol Evol 4: $16-20$

Walters CJ (1986) Adaptive management of renewable resources. Macmillan, New York 